\title{
PERILAKU MASYARAKAT DALAM PENCEGAHAN PENYAKIT DBD DI DESA BARIEH KECAMATAN MUTIARA TIMUR KABUPATEN PIDIE TAHUN 2018
}

\author{
T. Khairol Razi ${ }^{(1)}$, Fadli Syahputra ${ }^{(2)}$, Naiturrahmi ${ }^{(3)}$ \\ 1, 3Akademik Kesehatan Lingkungan Jabal Ghafur, Sigli \\ 2 Akademi Farmasi YPPM Mandiri, Banda Aceh \\ Email : 1tkhairolrazimt@gmail.com,2fadlimeuraxa@gmail.com
}

\begin{abstract}
ABSTRAK
Latar Belakang: Untuk pencegahan dan pemberantasan penyakit Demam Berdarah Dengue (DBD) merupakan tanggung jawab bersama baik antara pemerintah baik lintas sektor maupun lintas program dan masyarakat termasuk tugas dan tanggung jawab pemerintah dalam upaya pemberantasan penyakit DBD antara lain membuat kebijakan dan rencana yang strategis untuk penanggulangan penyakit DBD. Metode: Penelitian ini bersifat deskriptif yaitu untuk mengetahui Perilaku Masyarakat Dalam Pencegahan Penyakit DBD Di Desa Barieh Kecamatan Mutiara Timur Kabupaten Pidie. Yang menjadi populasi dalam penelitian ini adalah Kepala Keluarga yang ada di Desa Barieh Kecamatan Mutiara Timur Kabupaten Pidie sebanyak 125 Kepala Keluarga. Hasil: Berdasarkan Perilaku Masyarakat Dalam Pencegahan Penyakit DBD Di Desa Barieh Kecamatan Mutiara Timur Kabupaten Pidie Tahun 2018 sebagai berikut: Dari 55 responden yang dijadikan sampel maka dapat disimpulakan bahwa pengetahuan responden yang baik sebanyak 52 orang (94,5\%). Dari 55 responden yang dijadikan sampel maka dapat disimpulakan bahwa sikap responden yang baik sebanyak 52 orang $(94,5 \%)$. Dari 55 responden yang dijadikan sampel maka dapat disimpulakan bahwa tindakan responden yang baik sebanyak 41 orang $(74,5 \%)$. Dari 55 responden yang dijadikan sampel maka dapat disimpulakan bahwa prilaku responden yang baik sebanyak 50 orang (90,9\%). Saran: Sebaiknya responden selalu mengadakan gotong royong secara teratur, menggunakan kelambu saat tidur, menganti air vas bungan atau tempat minum burung secara teratur dan mengubur barang-barang bekas atau kaleng-kaleng bekas agar hidup menjadi bersih dan sehat.
\end{abstract}

Kata Kunci: Perilaku, Demam Berdarah Dengue (DBD)

\begin{abstract}
Background: For the prevention and eradication of Dengue Hemorrhagic Fever (DHF), it is a shared responsibility between the government both across sectors and across programs and the community, including the duties and responsibilities of the government in eradicating DHF, including making strategic policies and plans for the prevention of DHF. Methods: This research is descriptive in nature, which is to determine the Community Behavior in the Prevention of DHF in Barieh Village, Mutiara Timur District, Pidie Regency. The population in this study were 125 heads of families in Barieh Village, Mutiara Timur District, Pidie Regency. Results: Based on Community Behavior in Prevention of DHF in Barieh Village, Mutiara Timur District, Pidie Regency in 2018 as follows: Of the 55 respondents sampled, it can be concluded that 52 people (94.5\%) had good knowledge of respondents. Of the 55 respondents who were sampled, it can be concluded that the attitude of the respondents was good as many as 52 people (94.5\%). Of the 55 respondents who were sampled, it can be concluded that the respondent's actions were good as
\end{abstract}


many as 41 people (74.5\%). Of the 55 respondents who were sampled, it can be concluded that the good behavior of respondents was 50 people $(90.9 \%)$. Suggestion: It is better if respondents always hold mutual cooperation regularly, use mosquito nets while sleeping, change water from flower vases or bird drinking places regularly and bury used items or used cans so that life becomes clean and healthy.

Keywords: Behavior, Dengue Hemorrhagic Fever (DHF)

\section{PENDAHULUAN}

Menurut undang-undang RI. No. 36 Tahun 2009 Tentang Kesehatan pasal 152 pemerintah daerah dan masyarakat bertanggung jawab melakukan upaya pencegahan, pengendalian, dan pemberantasan penyakit menular serta akibat yang di timbulkan, untuk melindungi masyarakat dari tertularnya penyakit. Menurunkan jumlah yang sakit, cacat dan/atau meninggal dunia, serta untuk mengurangi dampak sosial dan ekonomi akibat penyakit menular. Dilakukan melalui kegiatan promotif, preventif, kuratif dan rehabilitatif bagi individu atau masyarakat.

DBD bisa menjadi penyakit yang paling menakutkan di musim hujan, bahkan di kala mewabah penyakit ini kerap meningkat kejadiannya dan tidak jarang menelan korban bahkan kasusnya makin meningkat dari tahun ke tahun. Di tahun 2004 penyakit ini menjadi berita utama hampir semua surat kabar nasional, semua rumah sakit kebanjiran DBD dan tidak sedikit kasus yang berakhir dengan kematian, hampir tidak ada daerah di Indonesia yang terbebas dari serangan penyakit DBD.

Untuk pencegahan dan pemberantasan penyakit DBD merupakan tanggung jawab bersama baik antara pemerintah baik lintas sektor maupun lintas program dan masyarakat termasuk tugas dan tanggung jawab pemerintah dalam upaya pemberantasan penyakit DBD antara lain membuat kebijakan dan rencana yang strategis untuk penanggulangan penyakit DBD. Masyarakat juga dapat ikut berperan serta dalam pemberantasan sarang vektor yang merupakan upaya paling penting untuk memutuskan mata rantai penularan dengan cara mencegah dan memberantas penyakit DBD yang akan muncul di masa akan datang. Berdasarkan data dari Puskesmas Ujong Rimba Kecamatan Mutiara Timur Kabupaten Pidie jumlah kasus DBD pada tahun 2014 sebanyak 9 kasus, 2015 sebanyak 17 kasus dan pada tahun 2016 sebanyak 14 kasus sedangkan pada tahun 2017 dari bulan Januari s/d November yaitu 10 kasus. Sedangkan di Desa Barieh terdapat 1 kasus demam berdarah pada tahun 2017 (Puskesmas Ujong Rimba, 2017).

Maka berdasarkan dari permasalahan yang ditimbulkan penulis berkeinginan mengambil judul Perilaku Masyarakat Dalam Pencegahan Penyakit DBD di Desa Barieh Kecamatan Mutiara Timur Kabupaten Pidie Tahun 2018.

\section{METODOLOGI PENELITIAN}

Penelitian ini bersifat deskriptif yaitu untuk mengetahui Perilaku Masyarakat Dalam Pencegahan Penyakit DBD di Desa Barieh Kecamatan Mutiara Timur Kabupaten Pidie Tahun 2018.

Populasi dalam penelitian ini adalah Kepala Keluarga yang ada di Desa Barieh Kecamatan Mutiara Timur Kabupaten Pidie sebanyak 125 KK. Sampel penelitian ini dihitung dengan menggunakan rumus Soekidjo Notoatmodjo 2005 yaitu didapat sebanyak 55 responden. Pengambilan sampel secara purposive sampling yaitu teknik penentuan sampel dengan pertimbangan tertentu.

Metode pengumpulan data yaitu menggunakan observasi dan wawancara 
Jurnal Sosial Humaniora Sigli (JSH)

p ISSN : 2615-3688

$e$ ISSN : 2716-0270

http://journal.unigha.ac.id/index.php/JSH

langsung dengan menggunakan fomulir yang sudah baku yaitu Kuesioner. Data yang diperoleh akan di olah secara manual dan melakukan rekapitulasi data agar memudahkan untuk tahapan selanjutnya.

Analisis data menggunakan univariat dilakukan untuk mengetahui distribusi dari masing-masing variabel yang akan disajikan dalam bentuk tabel distribusi frekuensi dan di berikan penjelasan dalam bentuk narasi.

\section{HASIL PENELITIAN}

Berdasarkan hasil penelitian yang telah penulis lakukan tentang Perilaku Masyarakat dalam Pencegahan Penyakit DBD di Desa Barieh Kecamatan Mutiara Timur, ialah dapat dilihat pada gambaran distribusi frekuensi Tabel 1 berikut ini.

Tabel 1. Analisis Univariat Distribusi Perilaku Masyarakat dalam Pencegahan Penyakit DBD di Desa Barieh Kecamatan Mutiara Timur Kabupaten Pidie Tahun 2018

\begin{tabular}{llcc}
\hline \multirow{2}{*}{ Variabel } & \multicolumn{2}{c}{ Jumlah } \\
\cline { 2 - 4 } 1. & Pengetahuan & N & \% \\
& Baik & 52 & 94,5 \\
& Kurang & 3 & 5,5 \\
\hline 2. & Sikap & & \\
& Baik & 52 & 94,5 \\
& Kurang & 3 & 5,5 \\
\hline 3. & Tindakan & & \\
& Baik & 41 & 74,5 \\
& Kurang & 14 & 25,5 \\
\hline 4. & Perilaku & & \\
& Baik & 50 & 90,9 \\
& Kurang & 5 & 9,1 \\
\hline \hline & \multicolumn{1}{c}{ Jumlah } & $\mathbf{5 5}$ & $\mathbf{1 0 0}$ \\
\hline
\end{tabular}

\section{PEMBAHASAN}

\section{Pengetahuan}

Menurut hasil penelitian yang penulis lakukan di Desa Barieh Kecamatan Mutiara Timur Kabupaten Pidie Tahun 2018, dapat kita lihat pengetahuan masyarakat yang kurang baik sebanyak 3 orang. Responden kurang mengerti tentang tanda gejala DBD, pecegahan sarang nyamuk Aedes Aegypty, pencegahan penyakit DBD, cirri-ciri nyamuk Aedes Aegypty dan waktu mengigit manusia. Diharapkan kepada masyarakat untuk dapat meningkatkan pendidikan dan pengetahuan dengan cara mengikuti penyuluhan kesehatan lingkungan, mengikuti selebaran / pamplet yang berhubungan dengan kesehatan guna untuk mengetahui cara hidup sehat dan cara pencegahan penyakit DBD yaitu dengan cara $3 \mathrm{M}$ : menguras tempat-tepat penampungan air, menutup rapat-rapat tempat penampungan air dan mengubur barangbarang bekas yang dapat menampung air hujan karena penyakit tersebut muncul akibat lingkungan yang tidak bersih dan sehat yang disebabkan oleh tangan manusia itu sendiri.

\section{Sikap}

Menurut hasil penelitian yang penulis lakukan di Desa Barieh Kecamatan Mutiara Timur Kabupaten Pidie Tahun 2018, dapat kita lihat bahwa sikap masyarakat yang kurang baik sebanyak 3 orang. Agar untuk mencegah terjadinya penyakit demam berdarah sebaiknya masyarakat lebih memperbaiki sikap sehari-hari dalam pencegahan penyakit demam berdarah yang di sebabkan oleh nyamuk. Sikap yang baik sangat berhubungan dengan kejadian penyakit demam berdarah apabila sikap baik maka resiko terkena penyakit demam berdarah lebih kecil dan sebaliknya apabila sikap masyarakat yang kurang baik dapat meningkatkan resiko terjadinya penyakit demam berdarah.

Penyebaran DBD dapat dicegah. Salah satunya dengan pengasapan atau fogging bermamfaat membunuh nyamuk aedes dewasa untuk mencegah penyebaran demam berdarah. Hingga kini, belum ada faksin atau obat antivirus bagi penyakit ini tindakan 
paling efektif untuk menekan epidemi demam berdarah adalah dengan mengontrol keberadaan dan sedapat mungkin menghindari vektor nyamuk pembawa virus dengue.

Mencegah lebih baik dari pada mengobati, hal utama yang dilakukan untuk mencegah demam berdarah adalah dengan menghindari gigitan nyamuk dari pagi sampai sore, karena nyamuk aedes yang merupakan penyebab utama demam berdarah lebih aktif disiang hari (bukan malam hari). Salah satu cara mencegah demam berdarah yaitu dengan menghindari digigit nyamuk misalnya hindarkan berada dilokasi yang banyak nyamuknya disiang hari, terutama didaerah yang ada penderita DBD nya.

\section{Tindakan}

Menurut hasil penelitian yang penulis lakukan di Desa Barieh Kecamatan Mutiara Timur Kabupaten Pidie Tahun 2018, dapat kita lihat bahwa tindakan masyarakat yang kurang baik sebanyak 14 orang, diharapkan pada semua masyarakat memakai pelindug saat tidur guna untuk mencegah dari gigitan nyamuk Aedes Aegypty dengan sendirinya dapat menurunkan jumlah kasus DBD dan dapat meningkatkan deraja kesehatan masyarakat, sebaiknya masyarakat agar barang-barang bekas atau kaleng-kaleng bekas dikubur agar tidak menampung air hujan supaya nyamuk Aedes Aegypty agar tidak bisa berkembangbiak, dan seharusnya masyarakat semua melakukan gotong royong seminggu sekali seperti membersihkan perkarangan rumah dari barang-barang yang dapat menampung air hujan, dengan cara menguburkan karena berpotensi sebagai tempat berkembangnya jentik-jentik nyamuk. Guna untuk mencegah terjadinya perkembangbiaknya nyamuk Aedes Aegypty dan tercipta suasana yang aman dan dapat menurunkan angka kesakitan dan meningkatkan derajat kesehatan masyarakat.

\section{Perilaku}

Menurut hasil penelitian yang penulis lakukan di Desa Barieh Kecamatan Mutiara Timur Kabupaten Pidie Tahun 2018, dari 55 responden maka perilaku masyarakat yang kurang baik sebanyak 5 orang. Adapun halhal yang mempengaruhi tentang perilaku masyarakat dalam pencegahan penyakit DBD disebabkan karena faktor pengatahuan, sikap dan tindakan yang masih sangat kurang bahkan sebagian masyarakat cenderung diabaikan karena dianggab tidak penting, hal ini perlu segera diperbaiki agar efeknya tidak berdampak pada kehidupan masyarakat. Maka untuk meningkatkan dan merubah halhal tersebut baik pengatahuan, sikap dan tindakan perlu dilakukan penyuluhanpenyuluhan dan informasi tentang masalah kesehatan sehingga terciptanya perilaku kehidupan yang baik bagi seluruh masyarakat.

\section{KESIMPULAN DAN SARAN Kesimpulan}

Berdasarkan hasil penelitian dapat diambil kesimpulan dari Perilaku Masyarakat Dalam Pencegahan Penyakit DBD Di Desa Barieh Kecamatan Mutiara Timur Kabupaten Pidie Tahun 2018 sebagai berikut:

1. Dari 55 responden yang dijadikan sampel maka dapat disimpulakan bahwa pengetahuan responden yang baik sebanyak 52 orang $(94,5 \%)$.

2. Dari 55 responden yang dijadikan sampel maka dapat disimpulakan bahwa sikap responden yang baik sebanyak 52 orang $(94,5 \%)$.

3. Dari 55 responden yang dijadikan sampel maka dapat disimpulakan bahwa tindakan responden yang baik sebanyak 41 orang $(74,5 \%)$. 
Jurnal Sosial Humaniora Sigli (JSH)

p ISSN : 2615-3688

$e$ ISSN : 2716-0270

http://journal.unigha.ac.id/index.php/JSH

4. Dari 55 responden yang dijadikan sampel maka dapat disimpulakan bahwa prilaku responden yang baik sebanyak 50 orang $(90,9 \%)$.

\section{Saran}

1. Sebaiknya responden lebih mendalami pengetahuan tentang faktor-faktor yang mempengaruhi kejadian DBD agar dapat mencegah terjadinya penyakit DBD yang disebabkan oleh nyamuk.

2. Sebaiknya responden mempertahankan sikapnya dan berusaha untuk meningkat sesuatu yang baik agar tercapai maksud dan tujuan bersama.

3. Sebaiknya responden selalu mengadakan gotong royong secara teratur, menggunakan kelambu saat tidur, menganti air vas bungan atau tempat minum burung secara teratur dan mengubur barang-barang bekas atau kaleng-kaleng bekas agar hidup menjadi bersih dan sehat.

\section{DAFTAR PUSTAKA}

Arman, E.P. 2005. Faktor Lingkungan dan Perilaku Kesehatan yang Berhubungan dengan Endemisitas Demam Berdarah Dengue. Surabaya.

D.W. 2007. Faktor-Faktor yang Berhubungan dengan Keberadaan Jentik Nyamuk. Seminar Hasil Penelitian \& Pengabdian kepada Masyarakat, Unila. Available from : http://lemlit.unila.ac.id.

Dep.Kes. RI., 1992 Dirjen Pemberantasan Penyakit Menular dan Penyehatan Lingkungan Pemukiman.

Junaidi, Turno, 2008, Pedoman Tata Laksana Karya Tulis Ilmiah (KTI), Sigli, Akademi Kesehatan Lingkungan Jabal Ghafur.

Mochammadi, N., Rosmanida, dan Yotopranoto, S. 2002. Analisis
Densitas Aedes aegypti pada Daerah Endemis Demam Berdarah di Kecamatan Sawahan Kotamadya Surabaya. Jurnal Penelitian Medika Eksakta 3 (3) : 242 - 252.

Notoatmodjo, Soekidjo., 2005. Metodologi Penelitian Kesehatan.

Notoatmodjo, Soekidjo., 2007. Kesehatan Masyarakat Ilmu dan Seni.

Rogers, 2004. Tentang Pengetahuan, Kesehatan Masyarakat.

Upikke, Penyakit-tular-vektor-demamberdarah-dengue, diakses pada tanggal 10 agustus 2012.

Nuidja, N., Sudarmanto, G. dan Hadi, C.M. 1997. Pengaruh Jenis Tempat Penyimpanan Air untuk Tirta terhadap Kepadatan Larva Aedes aegypti. Dep.Kes. Pendidikan Ahli Madya Sanitasi dan Kesehatan Lingkungan. Denpasar.

Ririh, Y., dan Anny, V. 2005. Hubungan Kondisi Lingkungan, Kontainer, dan Perilaku Masyarakat dengan Keberadaan Jentik Nyamuk Aedes aegypti di Daerah Endemis Demam Berdarah Dengue Surabaya, Jurnal Kesehatan Lingkungan 1 (2) : 170 182.

Saniambara, N., Effendi, A., dan Ndoen, E. 2003. Penyakit yang Ditularkan oleh Nyamuk di NTT. Available from: http://www.indomedia.com.

Soegijanto, S. 2004. Demam Berdarah Dengue. Surabaya: Airlangga University Press. Sumekar.

Sunaryo, S. 1988. Demam Berdarah Dengue Pada Anak, Jakarta: UI Widjana, D.P. 2003. Vektor Demam Berdarah 
Jurnal Sosial Humaniora Sigli (JSH)

p ISSN : 2615-3688

$e$ ISSN : 2716-0270

http://journal.unigha.ac.id/index.php/JSH

$\begin{array}{lcc}\text { Dengue. Denpasar: } & \text { Bagian } & \text { Zainudin, M. 1999. Metodelogi Penelitian. } \\ \text { Parasitologi FK Unud. } & \text { Surabaya: Fakultas Kedokteran } \\ & \text { Universitas Airlangga. }\end{array}$

Uwar, Cara pemberantasan 3M Plus.diakses

pada tanggal 10 Agustus 2012. 